\title{
HUBUNGAN ANTARA RIWAYAT STIMULASI MOTORIK KASAR DENGAN EMOSI ANAK
}

\section{THE RELATIONSHIP BETWEEN HISTORY OF ROUGH MOTOR STIMULATION AND CHILDREN'S EMOTIONS}

\author{
Yusnita $^{1}$, Nuria Mulyani ${ }^{2}$, Ita Paramita ${ }^{3}$ \\ ${ }^{123}$ Fakultas Kesehatan Universitas Muhammadiyah Pringsewu \\ Email: yusnita@umpi.ac.id
}

\begin{abstract}
The Relationship Between History Of Rough Motor Stimulation And Children's Emotions. The rough motor development of the child is problematic, the child becomes uncomfortable with his body, this will cause the child to easily fret, worry, and get angry. The purpose of this study was to find out the relationship between the history of rough motor stimulation and the child's emotions. This study used literature study techniques by analyzing 25 journals related to rough motor stimulation and emotions in children. The type of research that is widely used is quantitative. The samples in this study amounted to between 14 to 135 samples. With sampling techniques that dominate is total sampling. The most used data analysis is chi square test. The instruments used on average are questionnaires. The time of this research is March to August 2020. The results of the study were obtained by most children in KBRA Muslimat NU 16 Malang who have rough motor development that is in accordance with the stages of development and get good stimulation from their parents as much as $(60.7 \%)$. with a p value of $0.000<$ 0.05 . The majority of early childhood in terms of ability to manage self-emotions are at the level of developmental achievement rated BSH (Developing As Expected) with an average of 24.2 in one class. This means there is a link between a history of rough motor stimulation and the child's emotions. Suggestions for researchers can then be about motor stimulation with the child's emotions, and early handlers on the problem of lack of stimulation.
\end{abstract}

Keywords: children's emotions, History of rough motor stimulation

\begin{abstract}
Abstrak: Hubungan Antara Riwayat Stimulasi Motorik Kasar Dengan Emosi Anak. Perkembangan motorik kasar anak bermasalah, anak menjadi tidak nyaman dengan tubuhnya, hal ini akan menyebabkan anak mudah resah, cemas, dan marah. Tujuan dari penelitian ini mengetahui hubungkan antara riwayat stimulasi motorik kasar dengan emosi anak. Penelitian ini menggunakan tehnik studi literatur dengan menganalisa 25 jurnal yang berkaitan dengan stimulasi motoric kasar dan emosi pada anak. Jenis penelitian yang banyak digunakan adalah kuantitatif. Sampel dalam penelitian ini berjumlah antara $14 \mathrm{~s} / \mathrm{d}$ 135 sampel. Dengan tehnik pengambilan sampel yang mendominasi adalah total sampling. Analisis data yang terbanyak digunakan adalah uji chi square. Instrumen yang digunakan rata-rata adalah kuesioner. Waktu penelitian ini adalah Maret s/d Agustus 2020. Hasil penelitian didapatkan sebagian besar anak di KB-RA Muslimat NU 16 Kota Malang yang memiliki perkembangan motorik kasar yang sesuai tahapan perkembangannya serta mendapatkan stimulasi yang baik dari orangtua mereka sebanyak $(60,7 \%)$. dengan nilai $p$ value $0,000<0,05$. Mayoritas anak usia dini dalam hal kemampuan mengelola emosi diri berada tingkat pencapaian perkembangan dinilai BSH (Berkembang Sesuai Harapan) dengan rata-rata 24,2 pada satu kelas. Hal ini berarti terdapat hubungan antara riwayat stimulasi motorik kasar dengan emosi anak. Saran bagi peneliti selanjutnya dapat meneiliti tentang stimulasi motorik dengan emosi anak, dan penangan dini pada masalah kekurangan stimulasi.

Kata Kunci : Emosi anak, Riwayat Stimulasi Motorik Kasar
\end{abstract}


Vol 10 No 1 Januari 2021 | Page 48-53

\section{PENDAHULUAN}

Stimulasi merupakan kegiata merangsang kemampuan anak dan mempengaruhi pertumbuhan dan perkembangan anak serta menjadi penguat dalam proses perkembangan anak. stimulasi juga merupakan kebutuhan dasar anak yaitu asah yang akan menunjang perkembangan anak menjadi lebih optimal. Pemberian stimulasi akan lebih efektif apabila mempperhatikan kebutuhan anak sesuai dengan umur dan tahap perkembanganya (Depkes RI, 2011). Masalah yang sering terjadi pada anak usia dini yaitu masalah motorik, permasalahan motorik anak terdiri dari motorik kasar dan halus. Motorik kasar adalah perkembangan yang berhubungan dengan otot-otot besar missal seperti tengkurap, duduk, berjalan. Sedanngkan motorik halus adalah perkembangan gerak yang menggunakan otot-otot kecilnya, seperti otot di tangan dan jari untuk mengontrol benda berbagai bentuk (Soetjiningsih, 2017).

Terdapat perasaan kesal ketika gerakan tubuhnya tidak sesuai dengan harapanya sendiri. Jika hal ini di biarkan maka sikap emosional dan perilaku labil ini akan terbawa hingga anak besar dan menjadi bagian dari kepribadianya (Soetjiningsih, 2017). Bahaya dari kurangnya stimulasi motorik pada anak akan menyebabkan terjadinya gerakan motorik tidak bisa di control secara tidak sadar, terjadinya suatu gerakan-gerakan yang mendadak dan tidak disadari oleh dirinya dan memicu emosi anak tidak stabil. Pemberian stimulasi sebaiknya sesuai dengan tahap perkembangan anak dan peka terhadap kesiapan anak dalam menerima rangsangan. Pemberian stimulasi berlebih juga akan menimbulkan dampak negatif bagi anak misalnya anak yang semestinya belum berada pada tahap belajar berjalan, tetapi sudah dipaksa berjalan,berdiri atau ditatih, akibatnya struktur tulang kaki anak bisa terganggu (Soetjiningsih, 2017).

Menurut UNICEF (2011) didapat data masih tingginya angka kejadian gangguan pertumbuhan dan perkembangan pada anak usia balita. Khususnya gangguan perkembangan motorik pada anak didapatkan sebanyak $(27,5 \%)$ atau 3 juta anak mengalami gangguan. Hasil penelitian oleh (WHO, 2012) secara global di laporkan anak yang mengalami gangguan berupa kecemasan sekitar 9\%,mudah emosi 11-15\%, gangguan perilaku 9-15\%. Berdasarkan hasil riset kesehatan dasar persentase anak yang mengalami gangguan perkembangan motorik kasar di Indonesia sebesar 12,4\%. Walaupun angka ini menurun dibandingkan hasil Riskesdas tahun 2013 sebesar 8,8\% akan tetapi data menunjukan bahwa perkembangan motorik masih menjadi masalah kesehatan masyarakat yang utama (Riskesdas, 2018). Dari data Dinas Kesehatan Provinsi Lampung, hasil stimulasi deteksi intervensi dini tumbuh kembang (SDIDTK) anak balita pada tahun 2011 didapat gangguan perkembangan motorik kasar sebesar 20,3\%, pada tahun 2012 sebesar 19,7\% (Lampung, 2012).

Hasil penelitian yang dilakukan oleh S Muamanah. (2018) perkembangan emosi anak di Desa Bandar Abung Kec. Abung Surakarta, Kab. Lampung Utara kurang berkembang dengan baik hal ini terbukti dari kemampuan anak dalam memenuhi dan mencapai indikator sebagai berikut : anak yang belum berkembang 12 anak dengan jumlah prasentase 46,15\%, anak yang mulai berkembang 7 anak dengan jumlah prasentase $26,92 \%$, anak yang berkembang sesuai harapan 5 dengan jumlah prasentase $19,23 \%$, dan anak yang berkembang sangat baik 2 dengan jumlah prasentase 7,69\%, dari 26 anak didik.

https://ejournal.umpri.ac.id/index.php/JIK $\mathbf{4 9}$ 
Vol 10 No 1 Januari 2021 | Page 48-53

Data Pra Survey yang di peroleh dari TK KH.Gholib Pringsewu, jumlah keseluruhan anak di TK A1 dan TK A2 yaitu sebanyak 30 anak. Data tersebut terdiri atas TK A1 sebanyak 16 anak dan TK A2 sebanyak 14 anak. Dari hasil observasi dan wawancara dapat diambil kesimpulan bahwa perkembangan sosial emosi melalui permainan gerak, melompat dan melempar bola masih kurang berkembang dikarenakan sebanyak 8 anak di TK A1 dan A2 masih kurang memiliki rasa empaty terhadap temanya, dan masih kurang dalam membantu temanya yang kesulitan pada saat bermain. Sebagian anak juga ada yang belum bisa melakukan hal yang bisa meembuat permainan menjadi berhasil, 7 anak ada yang masih belum bisa menirukan gerakan yang diberikan guru.

\section{METODE}

Penelitian ini menggunakan tehnik studi literatur dengan menganalisa 25 jurnal yang berkaitan dengan stimulasi motoric kasar dan emosi pada anak. Jenis penelitian yang banyak digunakan adalah kuantitatif. Sampel dalam penelitian ini berjumlah antara 14 s/d 135 sampel. Dengan tehnik pengambilan sampel yang mendominasi adalah total sampling. Analisis data yang terbanyak digunakan adalah uji chi square. Instrumen yang digunakan rata-rata adalah kuesioner yang berisi tentang stimulasi orangtua, motorik kasar, emosi anak, Kuesioner Pra Skrining Perkembangan (KPSP) dan lembar observasi menggunakan Denver Developmental Screening Test (DDST). Waktu penelitian ini adalah Maret s/d Agustus 2020.

\section{HASIL}

Hasil Analisa dari 25 jurnal terkait, 80\% menyatakan ada hubungan antara stimulasi motoric dan perkembangan anak termasuk emosi pada anak. Hasil penelitian Dian samtyaingsih dan Afrihal afif ibaadillah, 2016. Tentang hubungan stimulasi orang tua dengan perkembangan motorik kasar pada anak usia 3-5 tahun di KB-RA Muslimat NU 16 kota malang, merupakan penelitian yang mendekati judul penelitain. 
Vol 10 No 1 Januari 2021 | Page 48-53

Tabel 1.1. Hubungan antara riwayat stimulasi motorik kasar dengan emosi anak Berdasarkan Hasil Literatur Review Jurnal

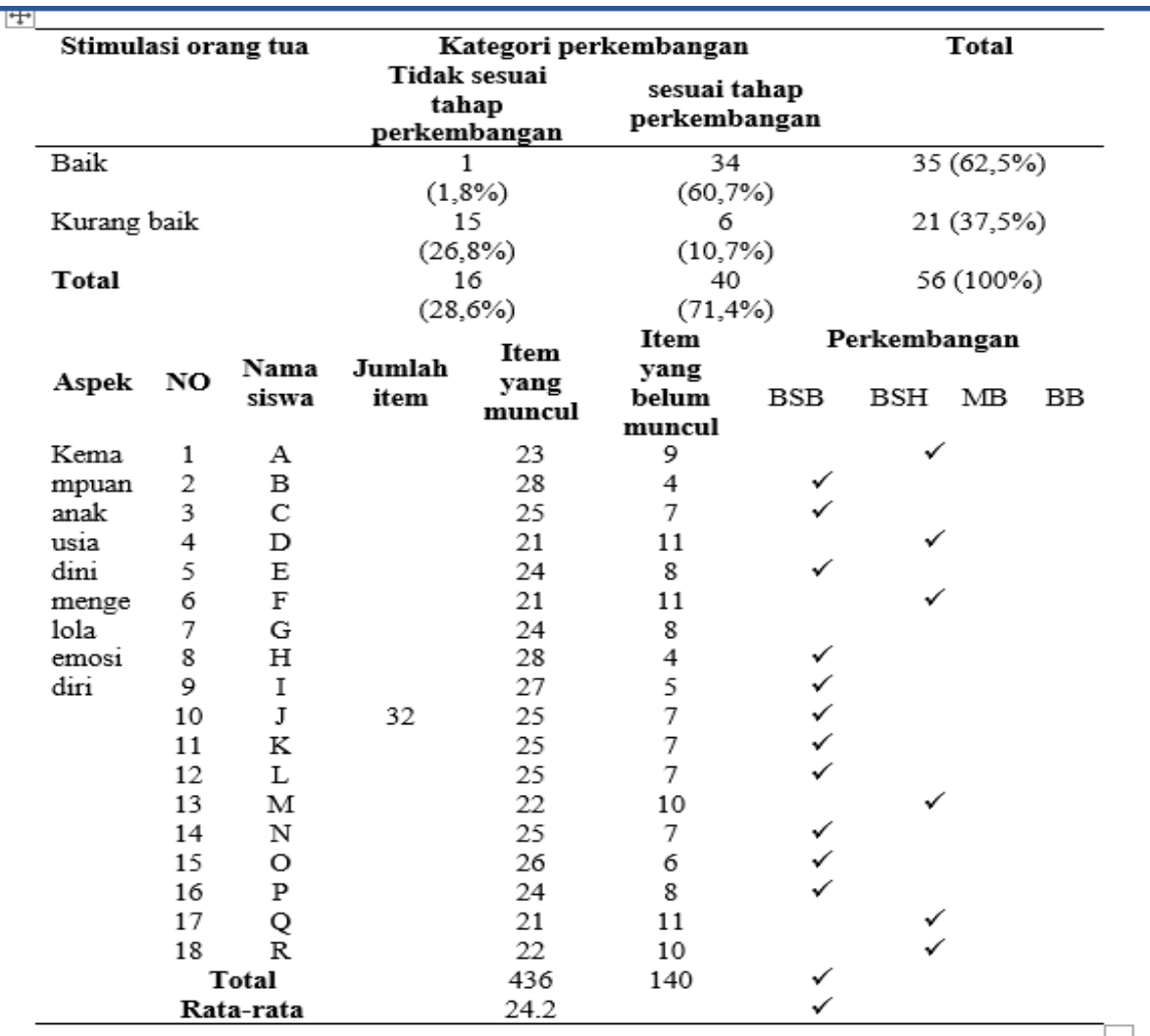

Hasil penelitian didapatkan sebagian besar anak di KB-RA Muslimat NU 16 Kota Malang yang memiliki perkembangan motorik kasar yang sesuai tahapan perkembangannya serta mendapatkan stimulasi yang baik dari orangtua mereka sebanyak $(60,7 \%)$. dengan nilai $\mathrm{p}$ value $0,000<0,05$. Mayoritas anak usia dini dalam hal kemampuan mengelola emosi diri berada tingkat pencapaian perkembangan dinilai BSH (Berkembang Sesuai Harapan) dengan jumlah total kemunculan sebanyak 432 item dengan rata-rata 24,2 pada satu kelas. Hal ini berarti terdapat hubungan antara riwayat stimulasi motorik kasar dengan emosi anak

\section{PEMBAHASAN}

Hasil penelitian menunjukkan bahwa sebagian besar anak di KB-RA Muslimat NU 16 Kota Malang yang memiliki perkembangan motorik kasar yang sesuai tahapan perkembangannya serta mendapatkan stimulasi yang baik dari orangtua mereka sebanyak $(60,7 \%)$. dengan nilai $p$ value 0,000 $<0,05$ dan mayoritas anak usia dini dalam hal kemampuan mengelola emosi diri berada tingkat pencapaian perkembangan dinilai BSH (Berkembang Sesuai Harapan) dengan jumlah total kemunculan sebanyak 432 item dengan rata-rata 24,2 pada satu kelas hal ini berarti terdapat hubungan antara riwayat stimulasi motorik kasar dengan emosi anak. Hasil tersebut sejalan dengan penelitian oleh Anugrah Indah Sari (2018) dengan judul Hubungan stimulasi ibu dengan perkembangan motorik kasar batita di posyandu di kelurahan penengahan raya kecamatan kedaton Bandar lampung 
didapatkan data sebanyak 39 dari $44(88,6 \%)$ anak yang mendapat stimulasi kategori baik memiliki perkembangan motorik kasar yang sesuai dan 5 dari $44(11,4 \%)$ anak memiliki suspek keterlambatan perkembangan motorik kasar. Untuk stimulasi kurang, hanya 22 dari 36 $(61,1 \%)$ anak yang memiliki perkembangan motorik kasar yang sesuai/normal dan 14 dari 36 anak $(38,9 \%)$ memiliki suspek keterlambatan perkembangan motorik kasar Hasil Uji ChiSquare didapatkan nilai $\mathrm{p}=0,004(\mathrm{p}<0,05)$. Terdapat hubungan antara stimulasi ibu dengan perkembangan motorik kasar batita.

\section{SIMPULAN}

Hasil penelitian dalam aspek kemampuan mengenal emosi diri mencapai tingkat perkembangan dengan kriteria BSH (Berkembang Sesuai Harapan) dengan jumlah total 106 item dengan rata-rata 5,8, Kemampuan mengatur emosi sesuai dengan situasi dan kondisi diri dominan mencapai tingkat perkembangan dengan kriteria BSB (Berkembang Sangat Baik) dengan jumlah total sebanyak 94 item dengan rata-rata 5,2 pada satu kelas. Berdasarkan hasil temuan dalam aspek Kemampuan memanfaatkan emosi diri secara positif mencapai perkembangan dengan kriteria BSB (Berkembang Sangat Baik) dengan jumlah total sebanyak 98 dengan rata-rata 5,4. Sedangkan dalam aspek kemampuan memiliki pertahanan diri dalam menghadapi setiap persoalan mencapai perkembangan dengan kriteria BSB (Berkembang Sangat Baik) dengan jumlah total sebanyak 124 dengan rata-rata 6,9. Ada hubungan antara riwayat stimulasi motorik kasar dengan emosi anak sehingga didapatkan nilai p-value $0,000<0,05$ yang artinya Ha diterima dan Ho ditolak.

\section{SARAN}

Untuk meneliti riwayat stimulasi motorik kasar tidak mudah karena membutuhkan ingatan yang baik dari orangtua, orangtua bisa lupa jika ditanyakan stimulasi apa yang telah mereka berikan kepada anaknya sewaktu usia balita, sehingga saran peneliti untuk untuk penelitian selanjutnya tentang stimulasi motorik baiknya ditentukan orangtua yang saat penelitian memiliki anak usia balita. Motorik terdiri dari motorik halus dan kasar, keduanya mempengaruhi perkembangan anak termasuk emosi anak, sehingga sebaiknya penelitian selanjutnya meneliti tentang stimulasi motorik halus dan motorik kasar. untuk peneliti selanjutnya bisa meneliti tentang penanganan dini terkait kurangnya stimulasi motorik kasar lainnya untuk mengatasi keterlambatan motorik anak.

\section{DAFTAR PUSTAKA}

A Sofia \& N Fatmawati. (2016). Pembelajaran motorik kasar melaluia permainan sirkuit warna. Jurnal Pendidikan Progresif. 2016. jurnal. fkip.unila.ac.id.

A Arini. (2019). Mengembangkan kemampuan motorik kasar anak melalui permainan outbond usia 45 tahun di TK Pembina kota agung tanggamus. Repository.radenintan.ac.id. 
Vol 10 No 1 Januari 2021 | Page 48-53

Anugrah Indah Sari. (2018). Hubungan Stimulasi Ibu dengan Perkembangan Motorik Kasar Batita Di Posyandu Di Kelurahan Penengahan Raya. Digilib.unila.ac.id

Dharma. (2011). Metodelogi penelitian keperawatan panduan melaksanakan dan menerapkan hasil penelitian. DKI Jakarta, CV.Trans Info Media.

Depkes RI (2011). Perkembangan Anak.

E Erlinda, IW Darmayana, N Syam (2014). Pengaruh motorik kasar anak Usia Dini Melalui permainan melempar dan menangkap bola di pendidikan anak usia dini islam terpadu al-ikhlas 1 kabupaten kepahiang. Repository.unib.ac.id

Lampung, P. K. P. (2012). Pelayanan kesehatan bayi dan balita.

EH Mulyana, G Gandana, MZN Muslim. (2017). Kemampuan Anak Usia Dini Mengelola Emosi Diri Pada Kelompok B di TK Pertiwi DWP Kecamatan Tawang Kota Tasikmalaya. Jurnal PAUD Agapedia. 2017. Ejournal.upi.edu.

YF Nadhirah, As-sibyan (2017). Perilaku Ketidak Matangan Sosial-Emosional Pada Anak Usia Dini. Junal Pendidikan Anak Usia Dini. 2017. 103.20.188.221

SS Ndari. (2018). Metode Perkembangan Sosial Emosi Anak Usia Dini. Jawa Barat: Edu Publisher.Edu.

Soetjiningsih. (2017). Buku Ajar Tumbuh Kembang Anak dan Permasalahannya. Jakarta: CV. Agung Sentosa

S Muamanah. (2018). Perkembangan Sosial Emosi Anak Usia 4-5 tahun di desa Bandar Abung Kecamatan Abungsurakarta Kabupaten Lampung Utara. UIN Raden Intan Lampung. 2018. core.ac.uk.

Riskesdas. (2018). Analisa Data Perkembangan Anak.

Riana, M. (2015). Emosi Anak Usia Dini dan strategi pengembanganya. Jakarta: PT Prenada Kencana Media

Satyaningsih Dian dan Ibadillah Afif. (2016). Hubungan Stimulasi orangtua dan perkembangan motoric kasar pada anak usia 3-5 tahun di KB-RA Muslimat NU 16 Kota Malang. Jurnal Wiyata. Vol.12. No.1.

Sumiyati dan Yulianti Retno. 2016. Hubungan Stimulasi dengan Perkembangan anak usia 4-5 tahun di Desa Karang Tengah Kecamatan Baturraden Kabupaten Banyumas. Jurnal LINK. ISSN 18295754.

Soetjiningsih. (2017). Tumbuh Kembang anak, Ed 2. Jakarta, Penerbit Buku Keddokteran EGC.

UNICEF. (2011). Programming Experiences in Early Child Devolpment.

IC Wati. (2016). Hubungan Stimulasi Perkembangan Terhadap Perkembangan Anak Usia 0-5 Tahun di RW 8 Kelurahan Kali Cari Kota Semarang. Jurnal Keperawatan. Fakultas Kedokteran. 2016. 